Dept. of Food Hygiene,

Fac. of Vet. Med., Cairo University,

Head of Dept. Prof. Dr. A. Morsy.

\title{
INCIDENCE OF PASTEURELLAE AMONG SLAUGHTERED SHEEP AND ITS EFFECT ON MEAT QUALITY \\ (With 5 Tables)
}

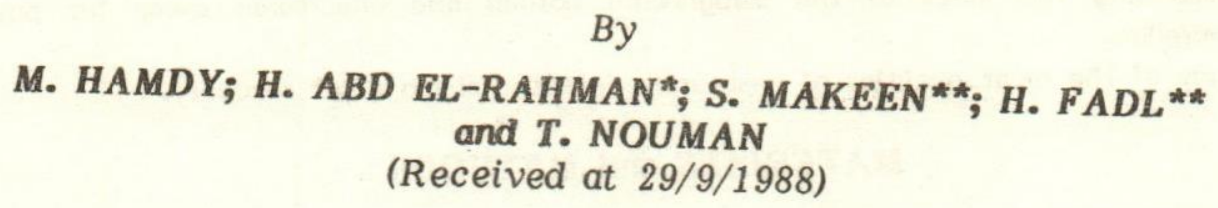

By M. HAMDY; H. ABD EL-RAHMAN*; S. MAKEEN**; H. FADL **
and T. NOUMAN

(Received at 29/9/1988)

\section{SUMMARY}

A total bf 150 lung samples ( 50 normal and 100 pneumonic) were collected from slaughtered sheep at Cairo abattoir and examined for the presence of pasteurellae. The incidence of pasteurellae among pneumonic and normal lungs were $23 \%$ and $6 \%$ respectively. Pasteurella multocida was recovered from $10 \%$ of pneumonic lungs, while Pasteurella haemolitica was isolated from only $20 \%$ of pneumonic lungs.

Five sheep were artificially infected by the isolated strains of P.multocida and were slaughtered after a therapeutic treatment. Significant differences were reported in living body weight, dressing-out percentage, the weight of the internal organs, fatty tissue, meat cuts grade I and III. Moreover, the chemical composition and the over eating quality test revealed also a considerable variation between the artificially infected and the controlled groups.

\section{INTRODUCTION}

Pasteurellae has a wide host spectrum and cause epidemic and septicemic diseases of both animals and birds. They have been incriminated as a primary or secondery cause of pneumonia (enzootic pneumonia); a cause of systemic pasteurellosis in animals and sometimes it is present as commensals in the respiratory tract and *: Dept. of Food Hygiene, Fac. of Vet. Med., Seuz Univ.

**: Vet. Serum and Vaccine Res. Institute, Ministry of Agriculture.

Assiut Vet.Med.J. Vol. 21, No. 42, 1989. 


\section{HAMDY, et al.}

nasal sinuses of persons associated with animals (GILMOUR and ANGUS, 1984). Concerning sheep, there is no doubt that pasteurellosis is one of the most important infectious diseases which causes economic loses not only due to high mortalities, but also due to loss in weight of pasteurellosis recovered sheep(WINKLER 1982). As far as no previous study was conducted on the meat quality of sheep previously infected with pasteurellosis, the present study was planned to investigate the following: 1- Aapitoring the lungs of the slaughtered normal and pneumonic sheep for pas-

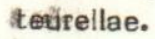

2- Study of the meat qualities of pasteurella infected sheep after recovery.

\section{MATERIALS and METHODS}

\section{1- Monitoring for pasteurellaes}

A) Collection of samples: 150 lung samples were collected from slaughtered sheep at Cairo abattoir. The samples were taking during the post-mortem inspection, pieces of lungs were taking during the post-mortem inspection, pieces of lungs were taken separately into sterile polythene bags. The samples were transferred to the laboratory without delay to be examined.

B) Detection of pasteurellae: The procedure adopted were done according to CRUICKSHANK et al. (1975).

C) Identification of pasteurellae: The isolated strains were identified according to BERGEY'S mannual (1984).

2- Study of the meat quality of pasteurella infected sheep after recovery from artificlal infection :

Ten male Osemi sheep nearly of the same age and an average live body weight of $22 \mathrm{Kg}$. were selected and observed for one month for healthy condition. Animals were fed on a balanced ration and kept under god hygienic condition.

Artificial infection : Before starting the experiment the animal weight was recorded. Five sheep were separated and had been infected with the isolated strains of P.multocida according to BAIN (1963) and BARAKAT et al. (1976).

Treatment: According to a performed antibiogram streptomycin injection 10 $\mathrm{mg} / \mathrm{Kg}$ twice daily for 5 successive days till the temperature drops and the animals started to restore appetite.

Slaughter and carcase evaluation: The methods adopted were carried out according to FABBRICANATE and SULTAN (1975).

Chemical analysis of the lean meat and fat : Were carried out according to the methods recommended by PEARSON (1976), HORWITZ et al. (1975) and the calorific value was calculated according to ALEXANDROV (1970).

Test panel evaluation : Were carried out according to MORE and IRITER (1970).

\section{RESULTS}

The results were tabulated in tables 1 to 5 . 
PASTEURELLAE AMONG SLAUGHTERED SHEEP

Table (1): Pasteurellae isolated from normal and pneumonic lung samples.

\begin{tabular}{|c|c|c|c|c|c|c|c|c|c|}
\hline \multirow{2}{*}{ Samples } & \multirow{2}{*}{ No. } & \multicolumn{2}{|c|}{$\begin{array}{l}\text { Total No.of } \\
\text { inf. sheep }\end{array}$} & \multicolumn{2}{|c|}{$\begin{array}{c}\text { Pdmultocida } \\
\text { infection }\end{array}$} & \multicolumn{2}{|c|}{$\begin{array}{l}\text { Phaemolytica } \\
\text { infection }\end{array}$} & \multicolumn{2}{|c|}{ Mixed infection } \\
\hline & & No. & $x$ & No. & $\%$ & No. & $\%$ & No. & $\%$ \\
\hline Pneumonic & 100 & 23 & 23 & 10 & 10 & 20 & 20 & 7 & 7 \\
\hline Normal & 50 & 3 & 6 & 3 & 6 & $\mathbf{0}$ & 0 & - & - \\
\hline
\end{tabular}

Table (2): Dressing percentages in both experiment and control sheep.

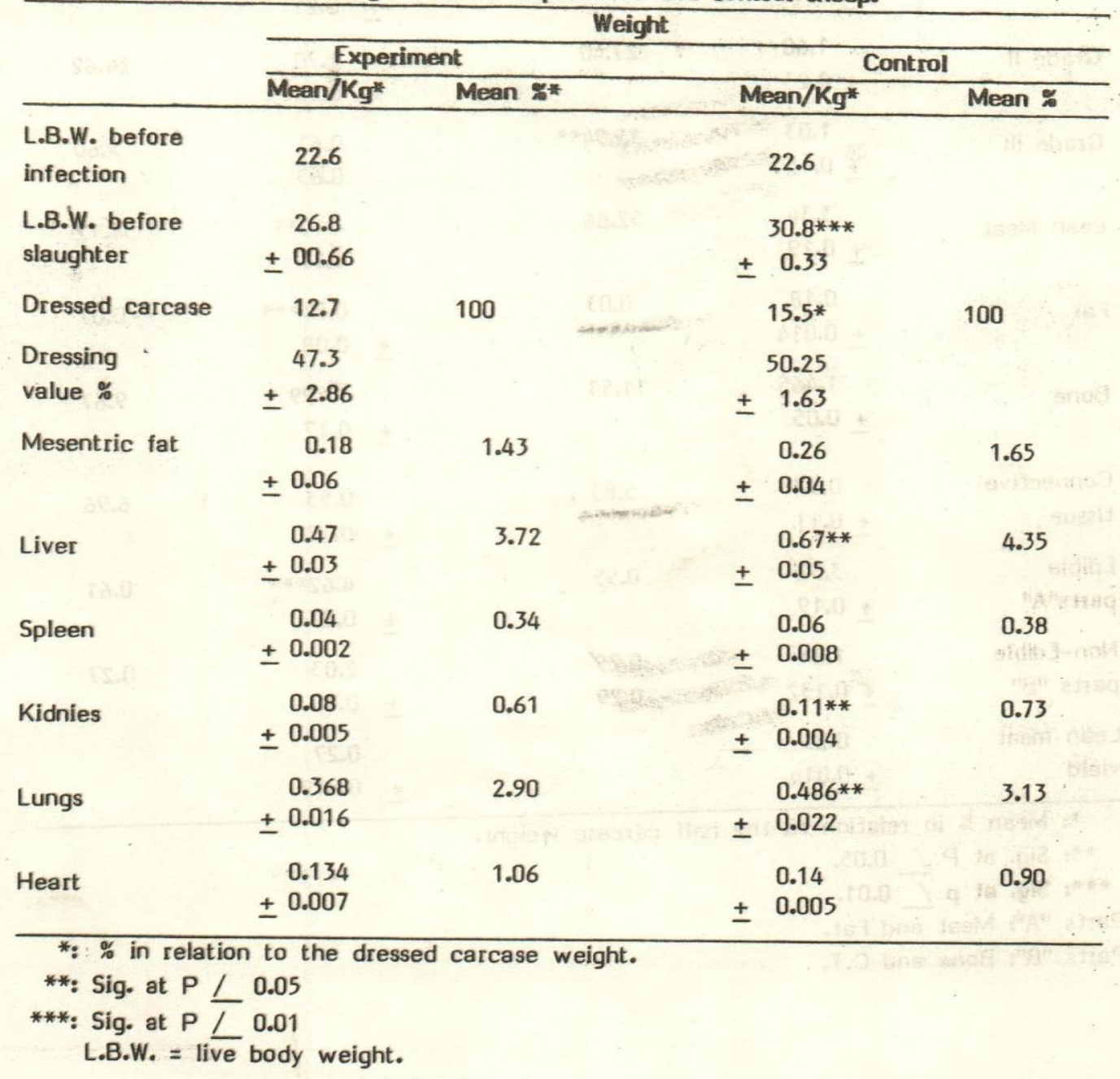


M. HAMDY, et al.

Table (3): Meat grades and carcase composition.

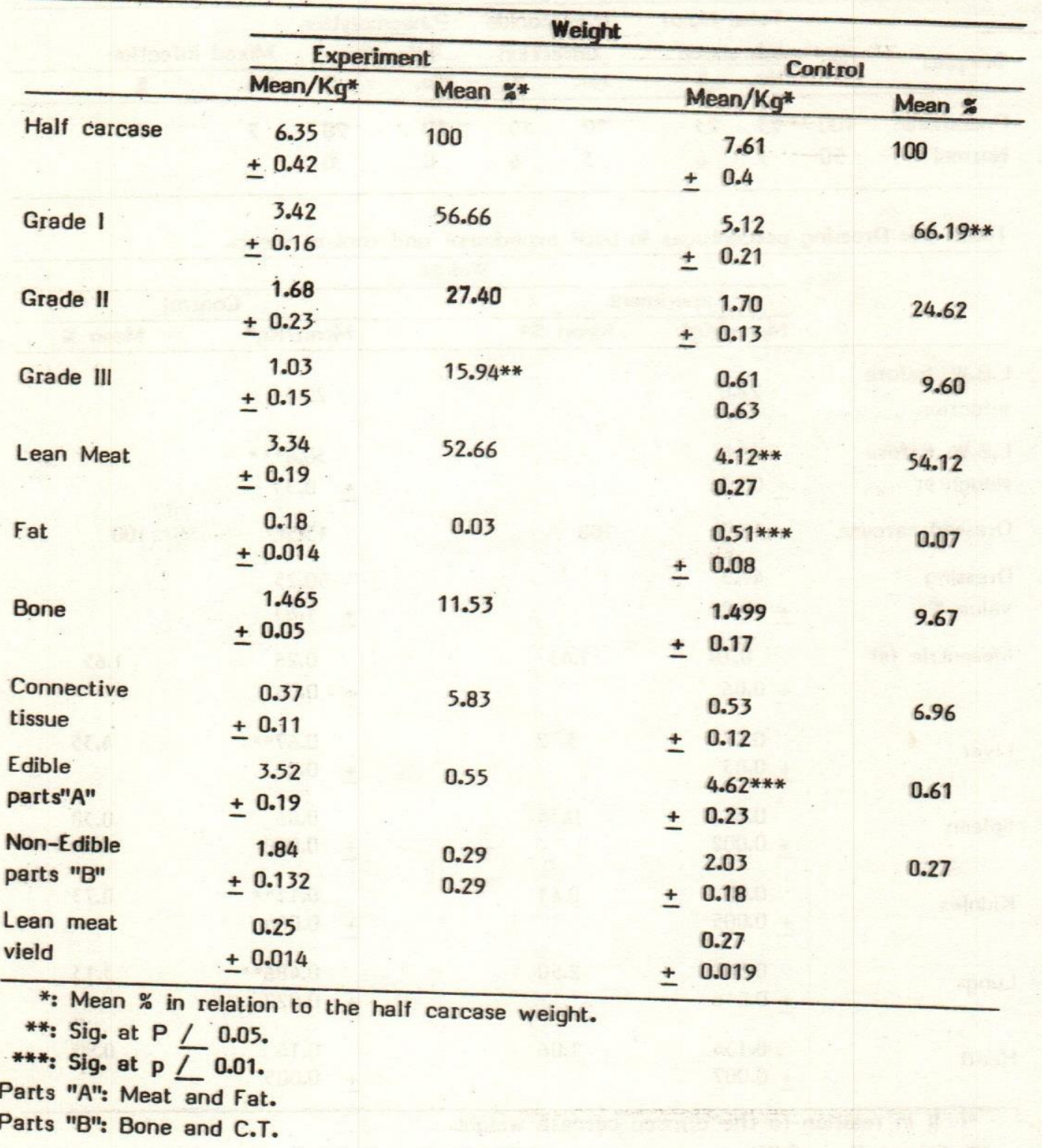

Assiut Vet.Med.J. Vol. 21, No. 42, 1989. 
PASTEURELLAE AMONG SLAUGHTERED SHEEP

Table (4): Panel test evaluation of meat.

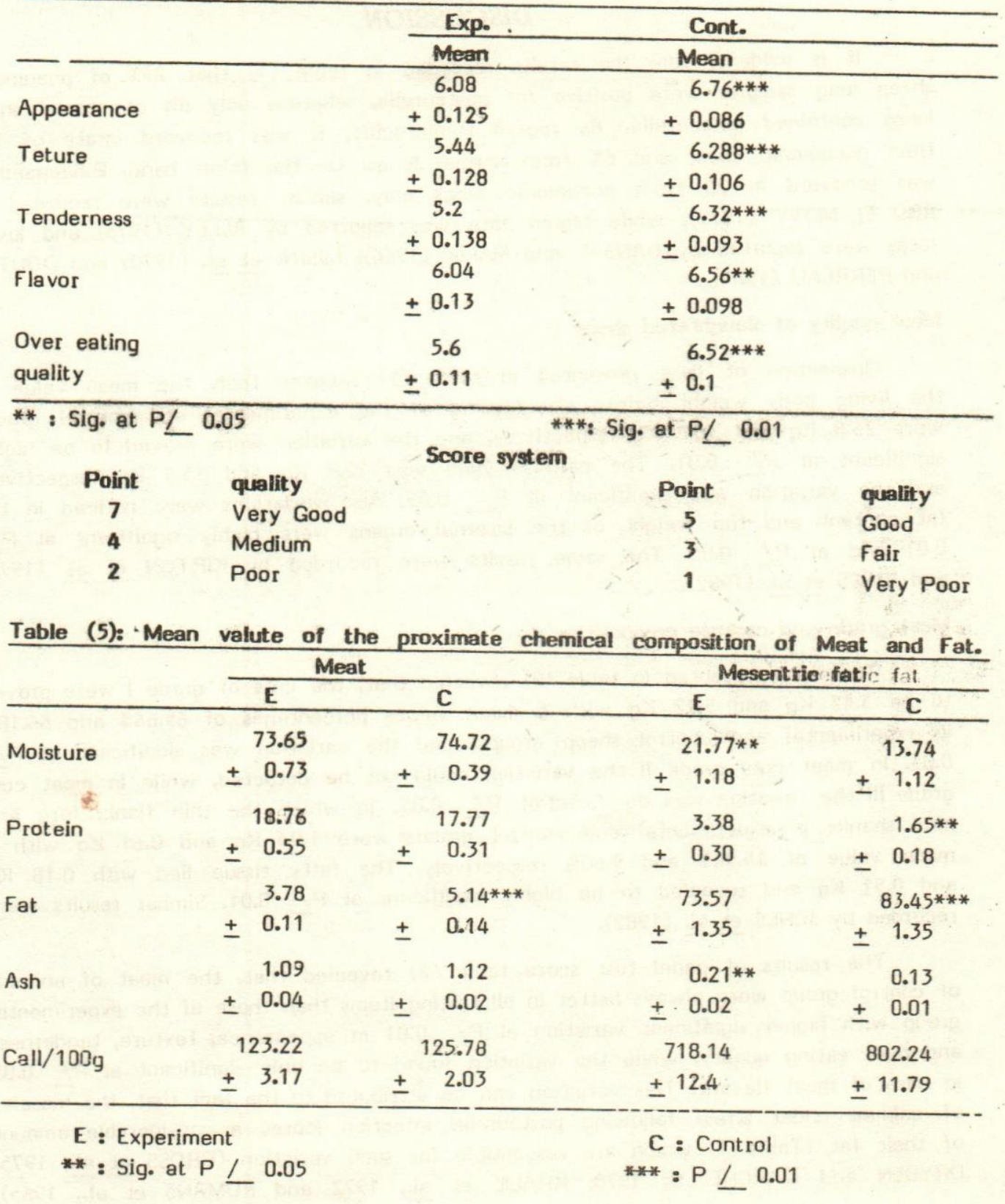




\section{HAMDY, et al.}

\section{DISCUSSION}

It is evident from the results recorded in table (1) that $23 \%$ of preumonic sheep lung samples were positive for pasteurella, whereas only $6 \%$ of normal sheep lungs contained pasteurella. As regard P.multocida, it was recoverd inrate of $10 \%$ from pneumonic case, and 6\% from normal lungs. On the other hand, P.haemolitica was recoverd in 20 from pneumonic lungs only. similar results were recorded by ABD EL-MOTY (1979), while higher rate was reported by ALLEY (1975) and lower rates were reported by BANSAL and MALIK (1966); MISRA et al. (1970) and DOUTRE
and PERREAU (1981).

\section{Meat quqlity of slaughtered sheep :}

Inspection of data presented in table (2) reveaed that, the mean value of the living body weight before slaughtering of the experimental and control groups were $26.8 \mathrm{Kg}$ and $30.8 \mathrm{Kg}$ respectively, and the variation were proved to be highly significant at $P / 0.01$. The carcase yield was $12.7 \mathrm{Kg}$ and $15.5 \mathrm{Kg}$ respectively and the variation was significant at $P / 0.05$. Also variations were noticed in the fat content and the weight of the internal organs were highly significant at $P$ / 0.01 and at $P / 0.05$. The same results were recorded by KIRTON et al. (1976) and JONES et al. (1982).

\section{Meat grade and carcase composition :}

The data presented in table (2) revealed that, the cuts of grade I were proved to be $3.42 \mathrm{Kg}$ and $5.12 \mathrm{Kg}$ with a mean values percentages of $65.66 \%$ and $66.10 \%$ in rxperimental and control sheep groups, and the variation was significant at $P$ / 0.05. In meat cuts grade II the variation could not be detected, while in meat cuts grade III the variation was significant at $P / 0.05$, in which the thin flank, fore and hind /shanks, in experimental uand: cantrol groupsinweren11.03 $\mathrm{Kg}$ and $0.61 \mathrm{Kg}$ with a mean value of $15.94 \%$ and $9.60 \%$ respectively. The fatty tissue lied with $0.18 \mathrm{Kg}$ and $0.51 \mathrm{Kg}$ and revealed to be highly significant at $P / 0.01$. Similar results were recorded by JONES et al. (1982).

The results of panel test score table (4) revealed that, the meat of animals of control group were always better in all tasting items than those of the experimental group with higher significant variation at $P / 0.01$ in appearance, texture, tenderness and over eating quality, while the variation found to be only significant at $P / 0.05$ in case of meat flavour. This variation can be attributed to the fact that, the muscles of animals under stress following pasteurella infection looses a considerable amount of their fat (Table 5) which are responsible for such variation (CROSS et al., 1975; DRYDEN and MARCHELLO, 1970; KHALIL et al., 1972 and ROMANS et al., 1965).

The chemical composition (Table 5) revealed that, the mean values percentages of moisture, protein, fat and ash were 73.6; 74.27; 18.7; 17.7; 3.7; 5.14 and 1.0, nificant variation at $P \perp 0.01$, while moisture and nificant variation. The meat of the experimental protein content revealed no sigal., 1981). 


\section{9

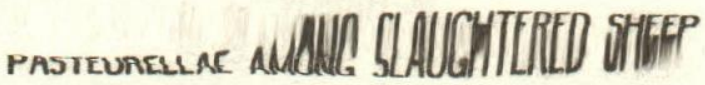

From the results obtained in this study, it is evident that significant differences were reported in: living body weight, dressing percentages, weight of the internal organs, meat cuts grade $\mathrm{I}$ and III, and in thefatty tissue of theartificial infected aimals. These differences in the quality of sheep meat were attributed to the stress effect of pasteurellae organisms on the living animals. Effort must carried out to control the pasteurellae infection in sheep flock by different methods of vaccination. Moreover occasion of pasteurellae infection, the slaughtering of the infected animals should be sustained for a sufficient period to allow the animals to regain the losses which were caused by such infection.

\section{REFERENCES}

Abd El-Moaty, S.E. (1979): Studies on Pasteurella mutocida of sheep Ph.D. Thesis, Fac. of Vet. Med. Assiut Univ.

Alexandrov, V.M. (1951): Otsenka catchestva Myasa, orenpo rg, USSR.

Alley, M.R. (1975): The bacterial flora of the respiratory tract of the normal and pneumonic sheep. Mewzland Vet. Journal.

Bain, R.V.S. (1963): Haemorrhagic septicaemia. F.A.O. Agric. Studies, No. 62.

Bansal, M.P. and Malik, B.S. (1966): Isolation of bacterial and viral agents associated 1. with lovine lung lesions. Indian Vet. Journal 43: 944-960.

Barakat, A.A.; El-Afandi, A.; Fayed, A.A.; Awad, H.H.; Shawkat, M.E. and Zahran, M. (1976): The susceptability of rhamani sheep to experimental infection with Pasteurella multocida. J. Egypt. Vet. Med. Assoc. 36: 3; 95.

Bergey, S. (1984): Bergey's mannual of systemic bacteriology, Vol. I. Krieg. NRR. and Holt, J.G. Wiliams and Wilkins. Bal./London.

Cross, H.R.; Abraham, H.C. and Knapp, B.M. (1975): Variatio in the amount and texture and distribution of the intramuscular fat within muscles of the beef carcase. J. Anim. Sci. 41.6; 1618.

Cruickshank, R.; Dugid, J.P.; Marmion, B.P. and Swain, R.H.A. (1975): Medical Microbiology. Ed. 12th. Churchill livingstone.

Boutre, M.P. and Perreau, P. (1981): Pasteurella and mycoplasma arginini carries in healthy sheep in Singhal. Revue d'elevage et de Medicine Veterinaire des pays Tropicaux.

Dryden, F.D. and Marchello, T.A. (1970): Influence of total lipid and fatty acids composition upon the palatability of three bovine muscles. J. Anim. Sci. 31(1): 36.

Fabbricante, T. and Sultan, W.J. (1975): Practical meat cutting and merchandising. Vol. 2, Avi. Westport. Connecticut. USA.

Gilmour, N.J.L. and Angus, K.W. (1983): Pasteurellosis in "Diseases of sheep" Ed. Martin, W.B. Black Well Sci. Publ. 3-8.

Horwitz, W.; Senzel, A.; Reynolus, H. and Park. D.l. (1975): Official Methods of Analysis of the Analytical Chemists. 12 Ed. Publ. AOAC, Washington.

Jones, G.E.; Field, G.J.S.; Nettlton, P.F. and Maclauchlan, M. (1982): Effect of the experimental chronic pneumonia on body weight, feed intake and carcase composition of lambs. Vet. Rec. 110, 168-173. 


\section{HAMDY, et al.}

Khalil, K.A.; Hobbs, C.S. and Winfree, S.K. (1972): Effect of fat deposition on beef palatability. J. Anim. Sci. 34, 1.346.

Kirton, A.A.; Ohara, P.J.; Shortridge, E. and Cordes, D.O. (1976): Newzland Vet. J. 24.59. Cited after Jones et al. (1982).

Misra, H.N.; Mullick, S.G.; Rao, C.C. and Khera, S.S. (1970): Analysis of results of bacteriological examination of morbid material from cases of sheep pneumonia during the period from 1959 to 1968. Indian Vet. J. 47: 714-720.

More, M.C. and Iriter, T.F. (1970): Introductory foods. McMillan Co. Lon.

Pearson, D. (1976): The chemical analysis of food. 7th Ed. Liv. Pub. Lon.

Riley, M.L.; Botkin, M.P.; Radolff, H.A. and Wieland, D.A. (1981): Effect of physical form of the diet and stress on the carcase characteristics of lamb. J. Anim. Sci. 53.6.1. 1489-1495.

Romans, I.R.; Tume, A.l.; Tucker, W.L. (1965): Influence of carcase maturity on the physical and chemical characteristics of beef palatabilty, fiber diameter andprovimate analysis. J. Anim. Sci. 24.3: 691-697.

Winkler, J.K. (1982): Farm animal health and disease control. 2nd Ed. London. 